BUNDA EDU-MIDWIFERY JOURNAL (BEMJ)

p-ISSN: 26227482 dan e-ISSN: 26227487

Vol. 4 No. 2 (2021)

\title{
HUBUNGAN KOMUNIKASI TERAPEUTIK BIDAN TERHADAP KEPUASAN IBU BERSALIN DI BPM MM KOTA SERANG
}

\section{Lusy Pratiwi}

Politeknik Tiara Bunda

Email: lusy22pratiwi@gmail.com

Keywords:

Communication, Therapeutic

Satisfaction

\begin{abstract}
Satisfaction is defined as the level of one's feelings after comparing the perceived performance (results) with their expectations, customer satisfaction is the main goal of excellent service so that every service apparatus is obliged to try to satisfy its customers. The purpose of this study was to determine the relationship between therapeutic communication and maternal satisfaction. The type of research used is quantitative research using a cross sectional research design. The population in this study were patients who gave birth at BPM MM Serang City. The sampling method using accidental sampling technique was obtained from April to May as many as 23 mothers giving birth. Data collection was done by using a questionnaire. The results that the researchers got were that there was a relationship between therapeutic communication and maternal satisfaction at BPM MM Serang City in 2021. The results of the frequency distribution study could be determined from 23 respondents showing that 10 respondents who had less satisfaction with a percentage of $56.9 \%$ while good satisfaction were 13. respondents with a percentage of $43.1 \%$. Patients who received low therapeutic communication were 10 respondents with a percentage of $56.9 \%$ while patients with high service quality were 13 respondents with a percentage of $43.1 \%$. It is expected that health workers, especially midwives, are able to provide care services for mothers when they help with childbirth, communication is fundamental to patient satisfaction.
\end{abstract}

\section{PENDAHULUAN}

Berdasarkan laporan World Health Organization (WHO) pada tahun 2019 Terdapat setidaknya 303 ribu wanita di seluruh dunia meninggal menjelang ataupun selama proses persalinan berlangsung. Tingkat kematian Ibu di Indonesia pada tahun 2019 angka kematian ibu berkisar 305 per 100.000. Dari 14.640 total kematian ibu yang dilaporkan hanya 4.999, berarti ada 9.641 yang tidak dilaporkan ke pusat. Dari data tersebut, ada 83.447 kematian ibu di desa maupun kelurahan, sementara di Puskesmas ada 9.825 kematian ibu, dan 2.868 kematian ibu di rumah sakit (Achadi, 2019).

Salah satu faktor yang berpengaruh terhadaap keselamatan persalinan adalah faktor kecemasan pada saat proses persalinan. Kecemasan yang terjadi pada ibu hamil dapat mempengaruhi kesehatan ibu maupun janin yang dikandungnya. Dalam 
hal ini, paritas sebagai salah satu koping yang mempengaruhi besarnya tingkat kecemasan dalam menghadapi proses persalinan.

Masalah yang sering terjadi dalam komunikasi bidan terhadap pelayanan INC adalah bidan tidak melakukan asuhan sayang ibu, kurang adanya kesabaran dalam menghadapi ibu bersalin. Komunikasi baik antara bidan dengan ibu bersalin sangat mempengaruhi kepuasan ibu bersalin dalam mendapat pelayanan oleh bidan. Sehingga dapat diperoleh rasa saling percaya antara bidan dan pasien. Hal ini dapat dilakukan dengan cara setelah melakukan komunikasi sebelum melakukan tindakan, bidan memberikan semangat dalam menghadapi persalinan, bidan mendengarkan dengan penuh perhatian apabila ada keluhan dari penderita menanggapi dengan baik apabila ada pertanyaan.

Konseling merupakan komunikasi interpersonal yang berkaitan dengan hak klien untuk memperoleh informasi, indikator mutu pelayanan kesehatan, membantu klien dalam menentukan pilihan, memahami kondisi yang dihadapi oleh klien, memberikan rasa puas pada klien (Saifuddin, sebagaimana yang dikutip oleh Yanuaria dalam Jurnal Vol. 1 No. 1 tahun 2013)

Komunikasi merupakan langkah pertama hubungan bidan dan pasien. Fokus komunikasi adalah kebutuhan pasien. Bidan harus mempertimbangkan beberapa faktor pada pasien termasuk kondisi fisik, keadaan emosional, latar belakang budaya, kesiapan berkomunikasi dan cara berhubungan dengan orang lain. Memilih waktu berkomunikasi juga penting saat bekerja dengan pasien (Sheldon, 2010).

Komunikasi terapeutik adalah komunikasi yang dilakukan atau dirancang untuk tujuan terapi. Seorang bidan dapat membantu klien mengatasi masalah yang dihadapinya melalui komunikasi, karena melalui komunikasi terapeutik bidan bisa membantu klien beradaptasi terhadap stres, mengatasi gangguan psikologis dan belajar bagaimana berhubungan dengan orang lain. (Nasir, 2009).

Salah satu yang utama dalam meningkatkan mutu pelayanan kesehatan dalam INC adalah bagaimana cara berkomunikasi dengan klien yang menarik sehingga klien merasa puas terhadap pelayanan. Dalam hal ini kepuasan yang akan lebih penting dalam pelayan kesehatan. Kepuasan pelayanan adalah suatu keadaan dimana kebutuhan, keinginan dan harapan ibu bersalin telah terpenuhi dari pelayanan yang telah diberikan oleh petugas kesehatan. Kepuasan pasien dapat juga diartikan sebagai tingkat perasaan pasien setelah membandingkan dengan harapannya.

Seorang pasien jika merasa puas dengan nilai yang diberikan oleh jasa pelayanan, sangat besar kemungkinannya untuk menjadi pelanggan dalam waktu yang lama. Kepuasan pasien merupakan reaksi perilaku sesudah menerima jasa pelayanan kesehatan. Hal itu mempengaruhi pengambilan keputusan pemanfaatan ulang yang sifatnya terus-menerus terhadap pembelian jasa yang sama dan akan mempengaruhi penyampaian pesan/kesan kepada pihak/orang lain tentang pelayanan kesehatan yang diberikan (Pohan, 2007).

Keterampilan berkomunikasi merupakan critical skill yang harus dimiliki oleh bidan, karena komunikasi merupakan proses yang dinamis yang digunakan untuk mengumpulkan data pengkajian, memberikan pendidikan atau informasi kesehatan dapat mempengaruhi klien untuk mengapikasikannya dalam hidup, menunjukkan caring, memberikan rasa nyaman, menumbuhkan rasa percaya diri dan menghargai nilai-nilai klien.

Berdasarkan hasil studi pendahuluan yang dilakukan oleh peneliti di wilayah kerja BPM MM pada bulan Maret tahun 2021 dari hasil wawancara 10 orang ibu bersalin merasa 
puas dengan komunikasi terapeutik bidan dalam pelayanan INC dan 5 orang ibu hamil yang merasa tidak puas.

Dari beberapa uraian di atas dan hasil studi pendahuluan, maka peneliti ingin melakukan penelitian dengan judul "Hubungan Komunikasi Terapeutik terhadap Kepuasan Ibu Bersalin di BPM MM Kota Serang Tahun $2021 ”$.

\section{METODE}

Jenis penelitian merupakan penelitian kuantitatif dengan rancangan penelitian menggunakan pendekatan cross sectional. Cross sectional merupakan suatu penelitian untuk mempelajari dinamika korelasi antara faktor-faktor resiko dengan efek, dengan cara pendekatan, observasi atau pengumpulan data sekaligus pada suatu saat. Populasi dalam penelitian ini adalah seluruh ibu bersalin pada bulan April sampai bulan Mei tahun 2021 sebanyak 23 orang dengan teknik pengambilan sampel yaitu total sampling yang berjumlah 23 orang. Lokasi pelaksanaan penelitian di BPM MM Kota Serang pada bulan April sampai bulan Mei tahun 2021. Instrumen dalam penelitian ini adalah kuesioner. Analisis data penelitian ini menggunakan analisis univariat dan analisis bivariat.

\section{HASIL PEMBAHASAN}

Analisis univariat digunakan untuk mendeskripsikan karakteristik dari variabel independen dan dependen. Keseluruhan data yang ada dalam kuesioner di olah dan disajikan dalam bentuk tabel distribusi frekuensi. Analisis Bivariat digunakan membuktikan hipotesis variabel terkait dengan variabel bebas dengan tingkat kemaknaan $p=$ value 0,05 .

\section{A. Analisis Univariat}

Tabel 1. Distribusi Responden Berdasarkan Variabel yang Diteliti

\begin{tabular}{lcc}
\hline Variabel & Frekuensi & \% \\
\hline Kepuasan & & \\
Kurang & 10 & 56,9 \\
Baik & 13 & 43,1 \\
Komunikasi & & \\
Terapeutik & & \\
Rendah & 10 & 56,9 \\
Tinggi & 13 & 43,1 \\
\hline
\end{tabular}

Berdasarkan dari tabel 1 diatas dengan distribusi frekuensi dapat ditentukan dari 23 responden menunjukan bahwa pasien yang mempunyai kepuasan kurang sebanyak 10 responden dengan persentase 56,9\% sedangkan kepuasan baik sebanyak 13 responden dengan persentase $43,1 \%$. Pasien yang mendapatkan komunikasi terapeutik rendah sebanyak 10 responden dengan persentase $56,9 \%$ sedangkan pasien dengan mendapatkan mutu layanan yang tinggi sebanyak 13 responden dengan persentase $43,1 \%$.

B. Analisis Bivariat

Tabel 2. Hubungan Komunikasi Terapeutik terhadap Kepuasan Ibu Bersalin

\begin{tabular}{|c|c|c|c|c|}
\hline \multirow{3}{*}{$\begin{array}{c}\text { Komunikasi } \\
\text { Terapeutik }\end{array}$} & \multicolumn{2}{|c|}{ Kepuasan } & \multirow[b]{2}{*}{ Total } & \multirow{3}{*}{$\mathrm{P}$} \\
\hline & Puas & $\begin{array}{l}\text { Tidak } \\
\text { Puas }\end{array}$ & & \\
\hline & $\mathrm{n}$ & $\mathrm{n}$ & $\mathrm{n}$ & \\
\hline \multirow{2}{*}{ Baik } & 5 & 5 & 10 & \multirow{4}{*}{0,000} \\
\hline & $50 \%$ & $50 \%$ & $100 \%$ & \\
\hline \multirow{2}{*}{ Tidak Baik } & 5 & 8 & 13 & \\
\hline & $38,5 \%$ & $61,5 \%$ & $100 \%$ & \\
\hline \multirow{2}{*}{ Total } & 10 & 13 & 23 & \\
\hline & $56,9 \%$ & $43,1 \%$ & $100 \%$ & \\
\hline
\end{tabular}

Berdasarkan tabel 2 hasil analisis bivariat menunjukkan adanya pengaruh mutu layanan dengan kepuasan pasien dan secara statistik signifikan $p<0,05(p=0,000)$

Pada hasil analisa data "Hubungan Komunikasi Terapeutik terhadap Kepuasan Ibu Bersalin di BPM MM Kota Serang" dengan menggunakan bantuan SPSS, dari hasil perhitungan didapatkan dengan nilai Sig $0,000<0,05)$. Hal ini berarti hipotesa 
penelitian ada hubungan antara pelaksanaan komunikasi terapeutik dengan kepuasan ibu bersalin di BPM MM Kota Serang tahun 2021. (Ho di tolak). Dalam penelitian ini pelaksanaan komunikasi terapeutik tidak mutlak dalam mewujudkan kepuasan bersalin dalam memperoleh informasi tentang kesehatan. Kemungkinan kepuasan pasien di MM Kota Serang bisa dipengaruhi karena bidan yang merawat selalu memperhatikan dan apabila dibutuhkan selalu cepat datang dan membantu pasien tersebut, bisa juga dipengaruhi oleh fasilitas, dan layanan yang diberikan.

Dalam penelitian Yuliani, "Hubungan Pelaksanaan Komunikasi Terapeutik Terhadap Kepuasan Pasien Sectio Caesaria (Sc) Di Ruang Bersalin Rumah Sakit Panti Waluya Malang" Pelaksanaan komunikasi terapeutik di ruang bersalin Rumah Sakit Panti Waluya sebagian besar pelaksanaan komunikasi terapeutik baik $(86,4 \%)$, dan sebagian kecil cukup $(13,6 \%)$. Kepuasan pasien SC di ruang bersalin rumah Sakit Panti Waluya Malang sebagian sangat puas $(50 \%)$ dan sebagian lagi puas $(50 \%)$. Analisa hubungan pelaksanaan komunikasi terapeutik terhadap kepuasan pasien SC di Ruang Waluya Malang dinyatakan tidak ada hubungan terbukti dengan hasil penghitungan dengan bantuan SPSS hasilnya adalah Sig 2 tailed $(\mathrm{p})=0,000$, dengan nilai Sig 2 tailed $(p)=0,000<0,05$. Kemungkinan kepuasan pasien bisa juga dipengaruhi oleh layanan yang didapatkan oleh pasien, suasana pelayanan, keakraban antara petugas dengan klien.

Dalam penelitian Lina Marlina "Hubungan Komunikasi Terapeutik Dengan Kecemasan Pasien Persalinan Kala 1 Fase Aktif Di Rsud Dr. Soekardjo Tasikmalaya" Sesuai degan hasil penelitian bahwa persentasi komunikasi terapeutik paling tinggi adalah kategori "kurang" sebanyak 13 orang (43.33\%), tingkat kecemasan paling tinggi adalah kategori "berat" sebanyak 20 orang $(66.66 \%)$. Hasil uji statistik menggunakan rank spearman diperoleh P-Value $=0.026$, nilai koefisien korelasi 0.463 , yang artinya adanya Hubungan Komunikasi Terapetik dengan Tingkat Kecemasan pada Pasien di Ruang Bersalin RSUD dr. Soekardjo Kota Tasikmalaya dengan tingkat keeratan hubungannya cukup. Melalui hasil penelitian ini, maka disarankan untuk bidan agar dapat memberikan pelayanan kesehehatan yang terbaik terhadap pasien dengan meningkatkan komunikasi terapeutik untuk mengurangi kecemasan pada pasien/ibu bersalin.

\section{KESIMPULAN DAN SARAN}

Hasil dari penelitian ini dapat disimpulkan bahwa terdapat hubungan komunikasi terapeutik bidan terhadap kepuasan ibu bersalin di BPM MM Kota Serang Tahun 2021.

Diharapkan tenaga Kesehatan khususnya bidan mampu memberikan pelayanan asuhan sayang ibu pada saat menolong persalinan, komunikasi adalah hal yang mendasar terhadap kepuasan pasien. Selalu menerapkan 5S pada saat pelayanan senyum, sapa, salam, sopan dan santun.

Melakukan komunikasi terapeutik kepada pasien tentunya akan membuat pasien puas, dan apabila pasien puas maka BPM akan banyak pasien, karena marketing di masyarakat "Mouth to mouth".

\section{DAFTAR PUSTAKA}

Achadi, EL (2019, February). Kematian Maternal dan Neonatal di Indonesia:disampaikan pada Rakernas 2019. Kemenkes RI.

Arikunto. 2013. Prosedur Penelitian. Jakarta: Rineka Cipta.

Depkes RI. 2010. Buku Saku Bidan. Jakarta. Irene

D.S. 2010. Manajemen Pemasaran Usaha Kesehatan. Jogjakarta : Nuha Medika. 
Nasir.2009. Komunikasi dalam keperawatan teori dan aplikasi. Jakarta :Penerbit Salemba Medika

Nurunniyah \& Nurhayati. 2013. Mutu Pelayanan Kebidanan. Yogyakarta: Fitramaya

Notoatmodjo, S. 2010. Metodologi Penelitian Kesehatan. Jakarta: PT. Rineka Cipta.

Pohan, Imbalo S. 2007. Jaminan Mutu Layanan Kesehatan: Dasar-Dasar Pengertian dan Penerapan, Jakarta: EGC.

Putri, Trikaloka H. 2013. Komunikasi Kebidanan. Yogyakarta: Mitra Setia

Riyanto, A. 2011. Aplikasi Metodologi Penelitian Kesehatan. Yogyakarta: Nuha Medika
Saifuddin. 2009. Buku Panduan Praktis Pelayanan Kesehatan Maternal dan Neonatal. Jakarta: Yayasan Bina Pustaka Sarwono Prawirohardjo.

Sheldon. 2009. Komunikasi Untuk Keperawatan. Erlangga.

Suryani. 2015. Komunikasi Terapeutik Teori dan Praktik Edisi 2. Jakarta: EGC

Wawan, A, Dewi. 2011. Pengetahuan, Sikap dan Prilaku Manusia. Yogyakarta: Nuha Medika. 